It is uncertain whether the abnormal findings indicate impaired liver function. It has been suggested that they may be a result of the pseudopregnancy state (Tyler, 1964). 'While the B.S.P.-removal mechanisms have been found to be impaired in normal pregnancy (Combes et al., 1963), the serum-transaminase levels and the standard B.S.P. retention are not abnormal (Christhilf et al., 1950 ; Combes et al., 1963 ; Ikonen, 1964). Mueller and Kappas (1964) in their patients, who were mostly post-menopausal, showed that natural oestrogens increased B.S.P. retention, but did not affect serumtransaminase levels. Lyndiol, with an oestrogenic component of $0.15 \mathrm{mg}$. per tablet, provoked abnormal serum-transaminase levels and B.S.P. retention more often than did Volidan with only $0.05 \mathrm{mg}$. of $17 \alpha$-ethinyloestradiol per tablet. This may be merely due to the fact that Lyndiol contains three times as much oestrogen as Volidan, but it is also possible that the 3-methoxy radical potentiates the effect of oestrogen on the liver. On the other hand, $17 \alpha$-ethynyloestrenol itself or one of its metabolites may also be an active principle. There is evidence that in man 19-norsteroids are converted into oestrogenic compounds (Goldzieher, 1964), and the progestogen component of Lyndiol might in this way potentiate the effect of synthetic oestrogen on the liver. It seems likely that oestrogens interfere with the transport of B.S.P. through the liver but not with its conjugation (Mueller and Kappas, 1964), as evidenced by the abnormally low B.S.P. clearance in post-menopausal women treated with oral contraceptives (Eisalo et al., 1964). Finally, it was surprising to find an almost identical incidence of abnormal results in the Orgametril and Volidan groups.

In conclusion, the serum transaminase levels and the B.S.P. retention should be determined in women taking oral contraceptive drugs, and withdrawal of medication should be considered in the event of abnormal results.

\section{Summary}

The incidence of abnormal liver-function tests was studied in 109 pre-menopausal women (mean age 29.4 years) taking contraceptive tablets.

Volidan was given to 45 women and Lyndiol to 39 women aged 17-41 years for contraception. Orgametril was administered therapeutically to 25 women aged 23-52. Standard liver-function tests were performed at regular intervals in every case.

The same low incidence of abnormal results was found in the Volidan and Orgametril groups, where serum-transaminase levels were raised in $4 \%$ of women and the bromsulphthalein retention was increased in $19 \%$. In the Lyndiol group, however, the incidence was much higher, with raised serum-transaminase levels in $18 \%$ of cases and increased B.S.P. retention in $48 \%$. In all cases the liver-function tests returned to normal within four weeks of withdrawal of the drug.

The above investigation was supported by a grant from the Sigrid Juselius Foundation.

\section{REFERENCES}

Bessey, O. A., Lowry, O. H., and Brock, M. J. (1946). F. biol. Chem., 164,321 .

Christhilf, S. M., and Bonsnes, R. W. (1950). Amer. F. Obstet. Gynec., 59,1100 .

Combes, B., Shibata, H., Adams, R., Mitchell, B. D., and Trammell, V. (1963). अ. S. clin. Invest., 42, 1431.

Eisalo, A., Järvinen, P. A., and Luukkainen, T. (1964). Brit. med. f., $2,426$.

Goldzieher, J. W. (1964). Med. Clin. N. Amer., 48, 529.

Ikonen, E. (1964). Acta obstet. gynec. scand., 43, Suppl. No. 5.

Linthorst, G. (1964). Brit. med. ₹., 2, 920.

Mueller, M. N., and Kappas, A. (1964). $尹$. clin. Invest., 43, 1905.

Swaab, L. I. (1964). Brit. med. 7., 2, 755 .

Tyler, E. T. (1964). Ibid., 2, 843.'

Wroblewski, F. (1958). In Advances in Clinical Chemistry, edited by H. Sobotka and C. P. Stewart, vol. 1, p. 313. Academic Press Inc., N.Y.

\title{
Stimulation of Gastric Intrinsic Factor Secretion
}

\author{
S. ARDEMAN,* M.A., B.M. ; I. CHANARIN, $\dagger$ M.D., D.C.P.
}

Brit. med. F., 1965, 1, 1417-1418

The parasympatheticomimetic drug carbachol when given to some patients with gastric atrophy increases the absorption of vitamin $B_{12}$ (Whiteside, Mollin, Coghill, Williams, and Anderson, 1964; Baker and Mollin, 1955). It was suggested, therefore, that carbachol stimulated the secretion of gastric intrinsic factor, and some support for this suggestion came from the report that it increased the concentration in gastric juice of substances binding vitamin $B_{12}$ (Gullberg, 1960). A similar increase in the vitamin- $B_{12}$-binding capacity of gastric juice after injection of methacholine (Mecholyl) was reported by Jeffries, Hoskins, and Sleisenger (1961).

With the introduction of methods for the direct assay of gastric intrinsic factor contradictory results were reported on the effect of cholinergic drugs. Ardeman, Chanarin, and Doyle (1964) found that the amount of intrinsic factor present in gastric juice after carbachol was no greater than that present before the carbachol was given. On the other hand, Jeffries,

\footnotetext{
* Member of the Scientific Staff, M.R.C. Experimental Haematology Research Unit, Wright-Fleming Institute of Microbiology, St. Mary's Hospital Medical School, London.

+ Senior Lecturer in Haematology, Department of Haematology, the Wright-Fleming Institute of Microbiology, St. Mary's Hospital Medical School, London.
}

Benjamin, and Sleisenger (1964) claimed that methacholine produced a rise in intrinsic factor output.

The purpose of this paper is to report further observations on the effect of cholinergic drugs on the secretion of intrinsic factor.

\section{Materials and Methods}

Gastric juice was collected continuously via a Ryle tube for one hour before and for one hour after administration of the substance under test. A full account of the methods for treating the samples of gastric juice and for assaying the intrinsic-factor content has been given elsewhere (Ardeman and Chanarin, $1963,1965)$. One unit of intrinsic factor has been defined as the amount that combines. with $1 \mu \mathrm{mg}$. of vitamin $\mathbf{B}_{12}$.

Subjects Studied.-Observations with the cholinergic drugs were made on 20 medical students and one patient with duodenal ulceration. In all, observations were made on 34 medical students, 25 patients with duodenal ulceration, and 38 other hospital patients.

Compounds Tested.-(1) Carbachol was given to 10 subjects in a $0.25-\mathrm{mg}$. dose, and to four in a $0.5-\mathrm{mg}$. dose. The larger 
dose produced cramp-like abdominal pain and urgency of micturition. (2) Methacholine chloride was given to five subjects either in a single $25-\mathrm{mg}$. dose or in divided doses over 30 minutes. (3) Bethanecol (Urecholine) was given to two subjects in a 5 -mg. dose. In addition, two medical students were given distilled water only, two were given saline injections, and three were given the histamine analogue, betazole hydrochloride (ametazole ; Histalog) at a dose level of $1.5 \mathrm{mg} . / \mathrm{kg}$. of body weight. Further observations on the effect of histamine and insulin are shown in the Table.

Effect of Stimulants on Intrinsic Factor Secretion

\begin{tabular}{|c|c|c|c|c|c|c|c|}
\hline \multirow{2}{*}{\multicolumn{3}{|c|}{ Stimulant }} & \multirow{2}{*}{$\begin{array}{c}\text { No. } \\
\text { of } \\
\text { Cases }\end{array}$} & \multicolumn{2}{|c|}{$\begin{array}{l}\text { Mean Secretion. } \\
\text { Resting } 1 \text { Hour }\end{array}$} & \multicolumn{2}{|c|}{$\begin{array}{c}\text { Mean Secretion. } \\
\text { Post-stimulant } 1 \\
\text { Hour }\end{array}$} \\
\hline & & & & $\underset{(\mathrm{mEq})}{\mathrm{HCl}}$ & $\begin{array}{l}\text { Intrinsic } \\
\text { Factor } \\
\text { (Units) }\end{array}$ & $\underset{(\mathrm{mEq})}{\mathrm{HCl}}$ & $\begin{array}{c}\text { Intrinsic } \\
\text { Factor } \\
\text { (Units) }\end{array}$ \\
\hline Water or saline & . & . & 4 & $1 \cdot 2$ & 1,500 & 30 & 2,800 \\
\hline $\begin{array}{l}\text { Histaminine } \\
\text { Insulin* } \\
\text { Betazole }\end{array}$ & $\because$ & $\begin{array}{l}\cdots \\
\cdots\end{array}$ & $\begin{array}{r}58 \\
11 \\
3\end{array}$ & $\overline{\overline{1}}$ & $\begin{array}{l}1,800 \\
1,900 \\
2,000\end{array}$ & $\bar{z}$ & $\begin{array}{r}7,700 \\
8,000 \\
14,300\end{array}$ \\
\hline $\begin{array}{l}\text { Carbachol } 0.25 \mathrm{mg} \text {. } \\
\text { Carbachol } 0.5 \mathrm{mg} \text {. } \\
\text { Methacholine } \quad \ldots \\
\text { Bethanecol }\end{array}$ & $\begin{array}{l}\cdots \\
\because \\
\cdots\end{array}$ & $\begin{array}{l}\cdots \\
\therefore\end{array}$ & $\begin{array}{r}10 \\
4 \\
5 \\
2\end{array}$ & $\begin{array}{l}2 \cdot 9 \\
2 \cdot 4 \\
1.0\end{array}$ & $\begin{array}{l}3,300 \\
3,500 \\
4,800 \\
3,000\end{array}$ & $\begin{array}{l}\frac{3 \cdot 2}{3 \cdot 2} \\
1 \cdot 8\end{array}$ & $\begin{array}{l}3,000 \\
3,900 \\
3,900 \\
4,000\end{array}$ \\
\hline \multicolumn{3}{|c|}{$\begin{array}{l}\text { All parasympatheticomimetic } \\
\text { drugs }\end{array}$} & 21 & $2 \cdot 1$ & 3,800 & $2 \cdot 7$ & 3,500 \\
\hline
\end{tabular}

- Including the observations reported earlier (Ardeman et al., 1964).

\section{Results}

Resting Secretion.-The intrinsic factor secreted over one hour in the absence of any stimulus ranged from 600 to 8,300 units (9 to 61 units $/ \mathrm{ml}$. gastric juice). The mean output in 97 subjects was 2,200 units and the mean concentration 34 units $/ \mathrm{ml}$. The subjects receiving the cholinergic drugs were young medical students, and the higher resting secretion of intrinsic factor in these (see Table) is probably related to their age as compared with the group receiving histamine, who were mostly older hospital patients.

Water or Saline.-There was no significant change in output of intrinsic factor after water or saline injections, and the mean concentration remained the same ( 34 units $/ \mathrm{ml}$.) (see Chart).

Betazole.-Injection of betazole hydrochloride (Histalog) was followed by a significant increase in both concentration and total output of intrinsic factor above the resting levels $(\mathrm{p}=$ 0.001 ). The output ranged from 9,300 to 18,600 units (mean

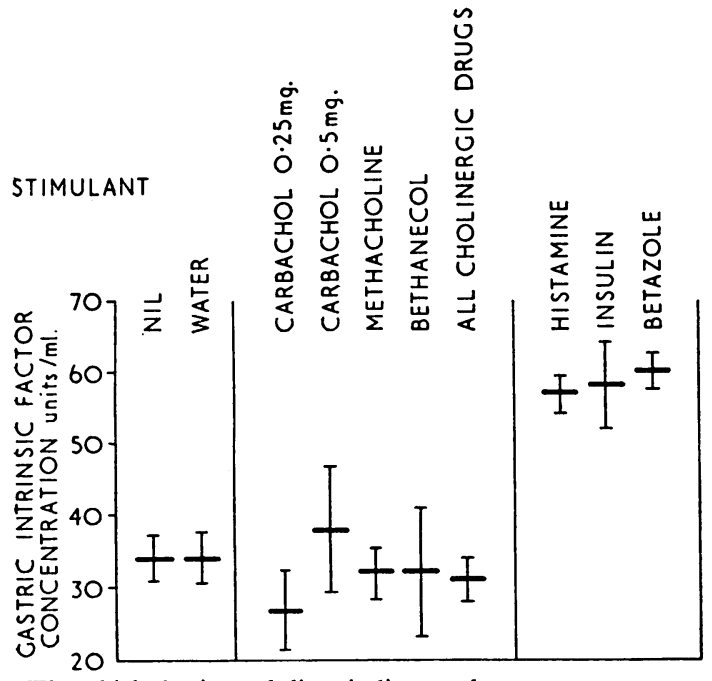

The thick horizontal line indicates the mean concentration of intrinsic factor in samples of gastric juice in this study. The thin horizontal lines indicate the standard error.
14,300 ) in an hour (concentration 55 to 63 units/ml., mean 60 units).

Cholinergic Drugs.-None of these drugs produced a significant increase in intrinsic factor output above the resting level.

Carbachol $(0.25 \mathrm{mg}$.).- The output of intrinsic factor varied from 1,000 to 8,100 units (mean 3,000 ). The concentration varied from 12 to 71 units (mean 27).

Carbachol $(0.5 \mathrm{mg}$.).-The output of intrinsic factor varied from 1,700 to 5,300 units (mean 3,900) units in one hour (24 to 60 units $/ \mathrm{ml}$., mean 38 ).

Methacholine Chloride.-The output of intrinsic factor varied from 2,300 to 6,400 units (mean 3,900), and concentration varied from 19 to 39 units $/ \mathrm{ml}$. (mean 32).

Bethanecol Chloride.-The output of intrinsic factor varied from 3,200 to 4,900 units (mean 4,000), and concentration varied from 23 to 41 units $/ \mathrm{ml}$. (mean 32 units).

\section{Conclusion}

The data presented in this paper confirm that cholinergic drugs do not stimulate the production of gastric intrinsic factor in normal subjects. It appears reasonable to suppose that they will not act in this way in patients with gastric atrophy as well, and the explanation for the beneficial action of these drugs on vitamin- $\mathrm{B}_{12}$ absorption in some patients with gastric atrophy must be looked for elsewhere than in an effect on the gastric mucosa. Possibly this effect may be related to increased small-intestinal peristalsis sending the small amount of vitamin- $\mathrm{B}_{12}$-intrinsic-factor complex down to the ileum before the reduced amount of intrinsic factor present in these patients is destroyed by proteolytic activity.

The histamine analogue betazole is a potent stimulant of the secretion of intrinsic factor. The amount of intrinsic factor produced after betazole (mean 14,300 units/hour) is greater than that obtained with histamine (7,700 units, with a concentration of 57 units $/ \mathrm{ml}$.). The greater output of intrinsic factor after betazole as compared with histamine seems to be related to its more prolonged action on the gastric mucosa, as demonstrated in the case of acid secretion by Zaterka and Neves (1964).

\section{Summary}

Gastric secretion of intrinsic factor was studied in 97 subjects, comprising 34 medical students, 25 patients with duodenal ulceration, and 38 other hospital patients. The mean resting secretion was found to be 2,200 units/hour.

Cholinergic drugs were given to 20 students and one patient with duodenal ulceration. Injections of carbachol, methacholine (Mecholyl), and bethanecol (Urecholine) given to 14, five, and two of these subjects, respectively, had no significant effect on the gastric secretion of intrinsic factor.

Betazole (Histalog), given to three students, was found to be almost twice as potent as histamine in stimulating secretion of intrinsic factor, probably owing to its more prolonged action.

We are indebted to Miss Valerie Berry for invaluable assistance both in carrying out the gastric aspirations and in the assay of intrinsic factor.

\section{REFERENCES}

Ardeman, S., and Chanarin, I. (1963). Lancet, 2, 1350.

Ardeman, S., and Chanarin, I. (1963). Lancet,

— - and Doyle, J. C. (1964). Brit. med. F., 2, 600.

Baker, S. J., and Mollin, D. L. (1955). Rev. Hémat., 10, 180. Gullberg, R. (1960). Proc. Soc. exp. Biol. (N.Y.), 105, 62. Jeffries, G. H., Beniamin, L. L., and Sleisenger, M. H. (1964). Clin. Res. Proc., 12, 209.

- Hoskins, D. W., and Sleisenger, M. H. (1961). Ibid., 9, 153. Whiteside, M. G., Mollin, D. L., Coghill, N. F., Williams, A. W., and Anderson, B.' (1964). Gut, 5, 385.

Zaterka, S., and Neves, D. P. (1964). Gastroenterology, 47, 251. 